\title{
Henneguya sacacaensis n. sp. (Myxozoa: Myxosporea) parasitizing gills of the acará bicudo Satanoperca jurupari (Osteichthyes: Cichlidae) in eastern Amazon
}

\author{
Henneguya sacacaensis no. sp (Myxozoa: Myxosporea) parasitando \\ brânquias do acará bicudo Satanoperca jurupari (Osteichthyes: Cichlidae) \\ na Amazônia oriental
}

\begin{abstract}
Roger Leomar da Silva Ferreira; Diehgo Tuloza da Silva²; Priscila Gomes de Araújo1; Igor Hamoy³; Edilson Matos²; Marcela Nunes Videira1* (1)

\footnotetext{
'Laboratório de Morfofisiologia e Sanidade Animal, Universidade do Estado do Amapá - UEAP, Macapá, AP, Brasil

${ }^{2}$ Laboratório de Pesquisa Carlos Azevedo, Universidade Federal Rural da Amazônia - UFRA, Belém, PA, Brasil

${ }^{3}$ Laboratório de Genética Aplicada, Universidade Federal Rural da Amazônia - UFRA, Belém, PA, Brasil
}

\begin{abstract}
How to cite: Ferreira RLS, Silva DT, Araújo PG, Hamoy I, Matos E, Videira MN. Henneguya sacacaensis n. sp. (Myxozoa: Myxosporea) parasitizing gills of the acará bicudo Satanoperca jurupari (Osteichthyes: Cichlidae) in eastern Amazon. Braz J Vet Parasitol 2020; 29(2): e000620. https://doi.org/10.1590/S1984-29612020030
\end{abstract}

\begin{abstract}
This study describes Henneguya sacacaensis n. sp. in specimens of the Osteichthyes Satanoperca jurupari (Heckel, 1840), collected in the Rio Curiaú Environmental Protection Area in the city of Macapá, state of Amapá Brazil. Using optical microscopy and molecular analysis, these cyst-shaped parasites were analyzed. The gills of 57.14\% of the analyzed S. jurupari contained hundreds of spores. The cysts found on the gill lamellae were oval-shaped and whitish. The Henneguya spores had an average length of 46.5 (41.3-56.92) $\mu \mathrm{m}$. The fusiform body of the Henneguya measured 16.5 (13.16-20.01) $\mu \mathrm{m}$ long and 5.1 (3.91-6.12) $\mu \mathrm{m}$ in width, the two polar capsules had a taper of 3.83 (3.4-4.32) $\mu \mathrm{m}$ and a width of 1.68 (1.4-1.99) $\mu \mathrm{m}$, and the tail measured $30(22.47-41.67) \mu \mathrm{m}$ in length, containing a polar filament coiled seven to nine times. Morphogical and phylogenetic analysis allowed the preposition of a new species, Henneguya sacacaensis $\mathrm{n}$. sp, that belongs to the family Myxobolidae and the genus Henneguya.
\end{abstract}

Keywords: Freshwater, Myxobolidae, fish, parasite, Amazon, gill.

\begin{abstract}
Resumo
Henneguya sacacaensis n. sp. é descrito em espécimes do Osteichthyes Satanoperca jurupari (Heckel, 1840), coletados na área de Proteção Ambiental do rio Curiaú na cidade de Macapá no estado do Amapá, Brasil. Com auxílio de microscopia óptica e análises moleculares, esses parasitos foram analisados e observados nas brânquias em forma de cistos, contendo centenas de esporos e apresentaram a prevalência de 57,14\%. Os cistos encontrados nas lamelas branquiais tinham formatos ovais e esbranquiçados. Seus esporos apresentaram um comprimento médio de 46,5 (41,3-56,92) $\mu \mathrm{m}$, corpo fusiforme medindo 16,5 (13,16-20,01) $\mu \mathrm{m}$ de comprimento e 5,1 (3,91-6,12) $\mu \mathrm{m}$ de largura, suas duas cápsulas polares apresentam uma conicidade de $3,83(3,4-4,32) \mu \mathrm{m}$ e sua largura $1,68 \mu \mathrm{m}$ $(1,4-1,99)$, a cauda $30(22,47-41,67) \mu \mathrm{m}$ de comprimento, contento um filamento polar de 7 à 9 voltas. Análises morfológicas e filogenéticas permitiram a preposição de uma nova espécie, Henneguya sacacaensis n. sp, que pertence à família Myxobolidae e ao gênero Henneguya.
\end{abstract}

Palavras-chave: Água doce, Myxobolidae, peixe, parasita, Amazônia, brânquia. 


\section{Introduction}

Myxozoa are endoparasites that can infect various organs and present high specificity (László et al., 2002). The genus Henneguya Thélohan, 1892 (Cnidaria: Myxobolidae) is one of the most diverse for the described species (Lom \& Dyková, 1992) within the Myxosporea class and is the second largest genus, with about 190 described species worldwide (Eiras \& Adriano, 2012).

Knowledge of parasitic biodiversity in South America is limited, especially in the Amazon region, due to the high ichthyofauna diversity and remoteness (Reis et al., 2016; Zatti et al., 2018). Recently Zatti et al. (2018) claim that 55 species of Henneguya spp. infect fish in Brazil. Of these, about 20 were found infecting fish species in the Amazon region (Velasco et al., 2016; Naldoni et al., 2018; Abrunhosa et al., 2018; Zatti et al., 2018).

The species of the genus Henneguya are predominantly histozoic, can infect various organs, and can cause considerable pathological changes (Dyková \& Lom, 1978; Molnár, 1998; Pote et al., 2000; Adriano et al., 2005; Naldoni et al., 2009; Barassa et al., 2012; Morsy et al., 2012; Mathews et al., 2016). When they infect the gills, they can cause filament destruction and respiratory failure (Lom \& Dyková, 1992).

Matos et al. (2004) describe that these are parasites of very different morphology and structure, found mainly in fish. The parasites are characterized by a complex life cycle, alternating between hosts, fish and invertebrates (Holzer et al., 2018).

The morphology of this genus is characterized by the number and shape of the spore valves, the position, number, and shape of the polar capsules (round, piriform, or ellipsoid), the relative position of the suture line, the presence of grooves and superficial appendages, and the number of coiled polar filaments (Feist \& Longshaw, 2006; Lom \& Dyková, 2006; Kaur \& Attri, 2015).

This study describes the morphological characteristics and molecular aspects of a new species of Myxozoa, Henneguya sacacaensis n. sp., found in the gills of S. jurupari. To date, no Myxobolidae has been recorded to infect this host.

\section{Material and Methods}

The 63 specimens used for this study were collected from the Curiaú River, Macapá, Amapá, Brazil $\left(0^{\circ} 8^{\prime} 43.6^{\prime \prime} \mathrm{N}\right.$, $51^{\circ} 2^{\prime} 30.3^{\prime \prime}$ W) (Figure 1). They were captured between September 2018 and September 2019 by the team at the Laboratory of Morphophysiology and Animal Health (LABMORSA) of the State University of Amapá (UEAP), with the help of local fishermen using a $30 \mathrm{~mm}$ cast net. The experiment was approved by the Animal Use Committee of the Brazilian Agricultural Research Company - Amapá (012-2018) and registered in the Biodiversity Authorization and Information System, IBAMA (SISBIO/ICMBIO License number 50376-1).

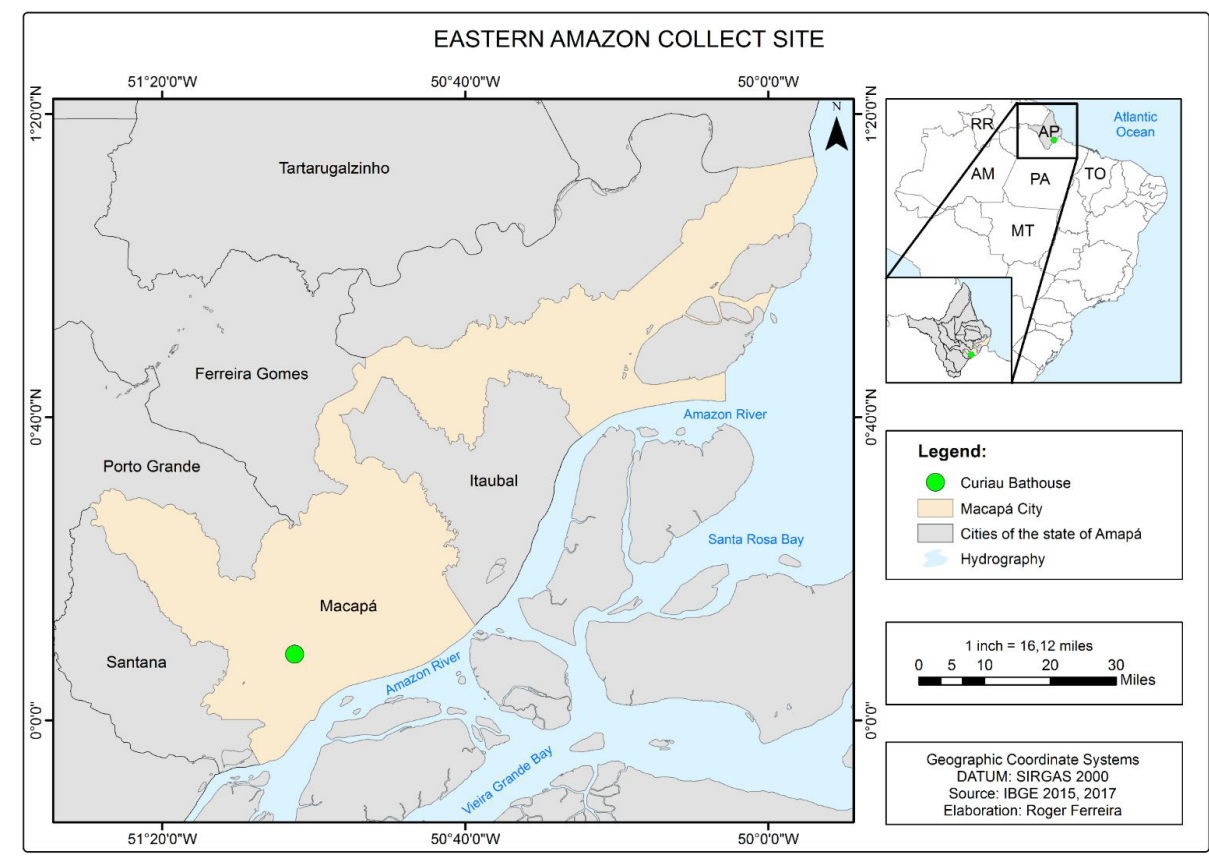

Figure 1. Map of the collection site in Macapá, Amapá: Rio Curiaú Environmental Protection Area, Eastern Amazon region. 
The captured animals were conditioned and transported alive to LABMORSA/UEAP in refrigerated boxes with portable pumps. They were acclimatized and stored in glass aquariums with electric pumps for aeration. Subsequently, parasitological analyses were performed.

In the aquariums, the animals were anesthetized with tricaine methanesulfonate (MS222 SIGMA) at a concentration of $50 \mathrm{mg} \mathrm{L}^{-1}$. Their body surface was examined with binocular stereoscopic microscopy to detect lesions (cysts) or loss of coating (scales and epidermis). Infectious foci of parasites in their developing and spore phases were found in the gall bladder. Small fragments were removed and observed with light microscopy (LM) to confirm parasitosis. Gall bladder fragments were fixed in Davidson's solution (70\% alcohol, formaldehyde, acetic acid, and distilled water) for 24 hours before paraffin embedding for histopathology. They were then stained with hematoxylin and eosin (H\&E) and Ziehl-Neelsen (ZN) and photographed at Carlos Azevedo Research Laboratory at the Federal Rural University of the Amazon (LPCA/UFRA). The methodology proposed by Bush et al. (1997) was used to calculate prevalence.

Cysts of eukaryotic microparasites were collected and stored in $80 \%$ ethyl alcohol at $4{ }^{\circ} \mathrm{C}$. The total DNA of each sample was extracted using the Wizard ${ }^{\circledR}$ Genomic DNA. DNA samples were quantified by spectrophotometry (Biodrop DUO).

All molecular analyses were based on the $18 \mathrm{~S}$ rDNA sequences, which were amplified using MC5/MC3 primers (Molnár, 2002). The final volume of the polymerase chain reaction (PCR) was of $25 \mu \mathrm{L}$ using taq DNA polymerase Master Mix (PROMEGA, Madison, USA), with $0.5 \mu \mathrm{M}$ of each primer and $2 \mu \mathrm{L}$ of the DNA sample. With the initial amplification being initiated by denaturation of $10 \mathrm{~s}$ at $95^{\circ} \mathrm{C}$, followed by 40 cycles of denaturation at $95^{\circ} \mathrm{C}$ for $1 \mathrm{~min}$, hybridisation at $48^{\circ} \mathrm{C}$ for $2 \mathrm{~min}$, and polymerisation for $4 \mathrm{~min} 30 \mathrm{~s}$ at $72{ }^{\circ} \mathrm{C}$, with final polymerisation of 10 min at $92^{\circ} \mathrm{C}$.

The amplicons were subjected to electrophoretic analyses through 1.5\% agarose gel purified using GFX'⿳⺈⿴囗十一 PCR DNA and Gel Band Purification Kit reagents were used to purify the material after PCR, as described by the manufacturer. These steps were performed at the Laboratory of Applied Genetics at the Federal Rural University of the Amazon (LGA/UFRA).

The amplification product was sequenced on an ABI 3730 automatic DNA analyzer using the BigDye Terminator v3.1 Cycle Sequencing Kit (Applied Biosystems). To confirm the observed mutations, the sample was sequenced with both forward and reverse primers. The nucleotide sequences obtained were edited and aligned using the BioEdit program (Hall, 1999). The phylogenetic relationship was obtained through maximum parsimony and Bayesian analyses, using the PAUP 4.0 b10 program (Swofford, 2003) for the former and the MrBayes 3.1.2 program (Ronquist \& Huelsenbeck, 2003) for the latter. Maximum parsimony analysis was performed with a heuristic search algorithm, in which equal weight was given for transitions and transversions, while insertions and deletions (indels) were treated as lost data. The confidence level of the most parsimonious tree nodes was evaluated by 1,000 bootstrap replicates (Felsenstein, 2004).

In the Bayesian analysis (BI), two parallel runs of four simultaneous searches were performed using the Markov chain Monte Carlo method (MCMC) for 5,000,000 generations each, sampling one tree every 1,000 generations and discarding the results of the first 1,250 trees ( $25 \%$ of the sample). The remaining 3,750 trees were used to estimate the confidence level (subsequent probability) of each node in the phylogenetic reconstruction. In the cladogram analysis, the DNA sequences of the organisms used were obtained directly from GenBank.

As indicated by JMODELTEST 2.0.2 (Darriba et al., 2012), BI analysis assumed a GTR + G model of nucleotide substitution with estimated nucleotide frequencies $(A=0.2520, C=0.1844, G=0.2831, T=0.2805)$, substitutions $(\mathrm{A}-\mathrm{C}=1.3916, \mathrm{~A}-\mathrm{G}=1.0936, \mathrm{~A}-\mathrm{T}=1.3916, \mathrm{C}-\mathrm{G}=1, \mathrm{C}-\mathrm{T}=4.3568, \mathrm{G}-\mathrm{T}=1)$, and rates for variable sites following a gamma distribution $(\mathrm{G}=0.4200)$ and $p$-inv 0.1990 .

\section{Results}

\section{Vegetative phase}

Henneguya parasites can form cysts at various sites in the gill filaments, and infection can be characterized as lamellar (Molnár, 2002). Stereomicroscope analysis under incident light showed whitish cysts and ellipsoids in a thin layer of connective tissue (Figure 2A). 


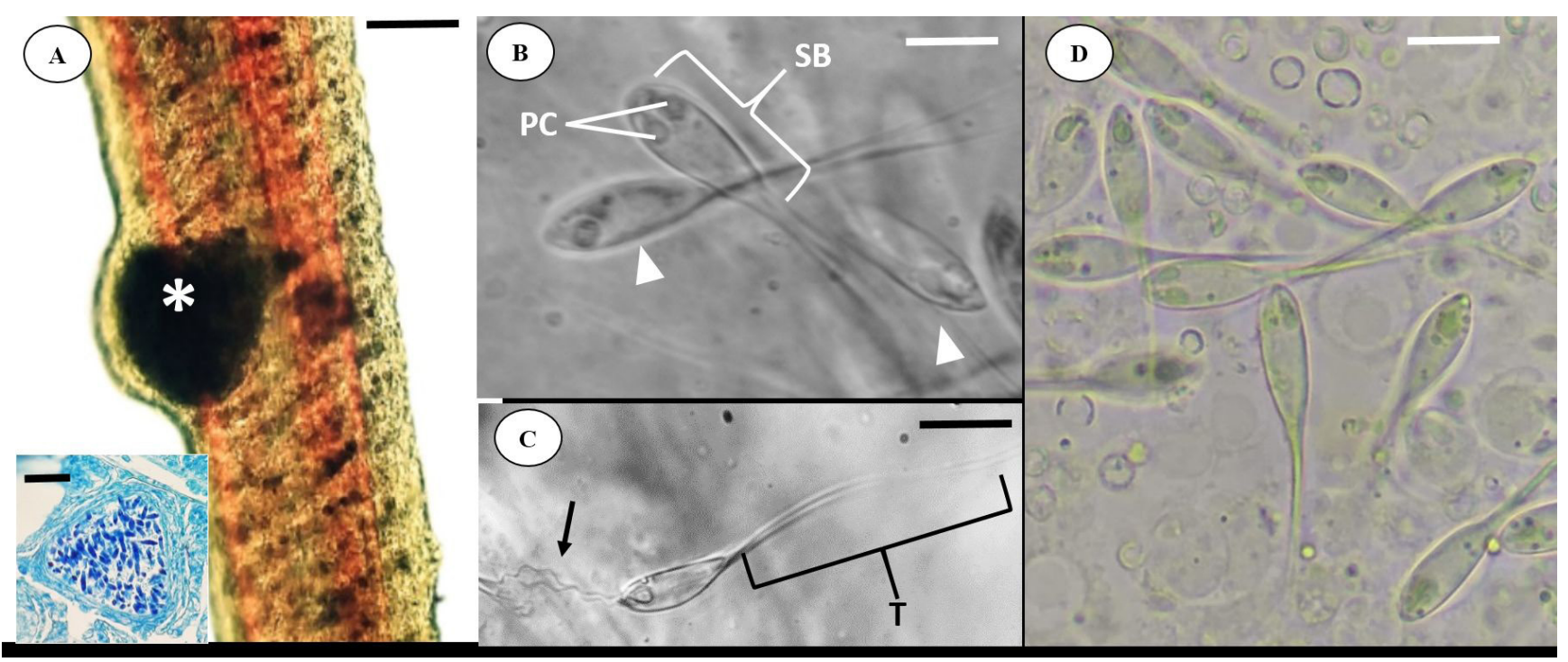

Figure 2. (A) Light microscopy of the Satanoperca jurupari gill filament with a myxosporid cyst Henneguya sacacaensis $\mathrm{n}$. sp. (asterisk). Scale bar: $10 \mu \mathrm{m}$. Inset: Histological section of a cyst in the Ziehl-Neelsen-stained gill filament. Scale bar, $5 \mu$ m; (B) H. sacacaensis n. sp. spores highlighting the polar capsules (PC) and the sporal body (SB). Scale bar, $10 \mu \mathrm{m}$; (C) H. sacacaensis n. sp. spore highlighting the fuzzy polar filament (arrow) and its tail (T). Scale bar, $10 \mu \mathrm{m}$; (D) Conventional light microscopy imaging of $H$. sacacaensis n. sp. spores. Scale bar, $10 \mu \mathrm{m}$.

\section{Spores}

Fresh spores were measured ( $n=31$ ) (Figure 2B, C, D). Average total lengths were $46.5 \pm 5.47 \mu \mathrm{m}$; spores bodies averaged $16.5 \pm 2.64 \mu \mathrm{m}$ in length and $5.1 \pm 0.94 \mu \mathrm{m}$ in width. The two polar capsules have a taper $3.83 \pm 0.31 \mu \mathrm{m}$ in length and $1.68 \pm 0.20 \mu \mathrm{m}$ in width, with the tail measuring $30 \pm 6.87 \mu \mathrm{m}$ long. Each capsule contained a polar filament coiled seven to nine times (Table 1).

\section{Taxonomy}

KINGDOM Metazoa Linnaeus, 1758

PHYLUM Cnidaria Hatscheck, 1888

SUBPHYLUM Myxozoa Grassé, 1970

CLASS Myxosporea Bütschli, 1881

ORDER Bivalvulida Shulman, 1959

FAMILY Myxobolidae Thélohan, 1892

GENUS Henneguya Thélohan, 1892

SPECIES Henneguya sacacaensis n. sp. (Figure 3)

HOST: Satanoperca jurupari Heckel, 1840

Site of infection: Henneguya cysts in the gill filaments.

Collection site: Rio Curiaú Environmental Protection Area, Macapá, Amapá (08'43.6" N, 51²'30.3" W).

Prevalence: Forty-three of 63 specimens analyzed (68.25\%)

Species deposit: Glass slide with H\&E-stained spores was deposited in the collection of the Amazon Research Institute (INPA), Manaus, in the state of Amazonas, Brazil (accession number INPA 60).

Etymology: The epithet of this genus is in honor of Raimundo dos Santos Souza, popularly known as "Sacaca", due to his contribution to Amapá popular culture.

The partial sequence of the SSU rDNA obtained from the species under study contains 1335 bp (GenBank accession number MT137652). For phylogenetic analysis, were used 38 South American sequences of Myxobolus spp. and Henneguya spp. available on Genbank. In the Bayesian inference analysis, Henneguya spp. formed a monophyletic group distributed in two clades, clade A, which includes Henneguya species that parasitize several fish species, mainly from the families Cichlidae and Pimelodidae, and clade B, which includes Myxobolus spp. parasites that infect organisms from the Amazon region (Figure 4). In comparisons between Henneguya spp. species that parasitize cichlids in the Amazon, there was a genetic $p$-distance ranging from 2.911 to $8.597 \%$ (Table 2). 


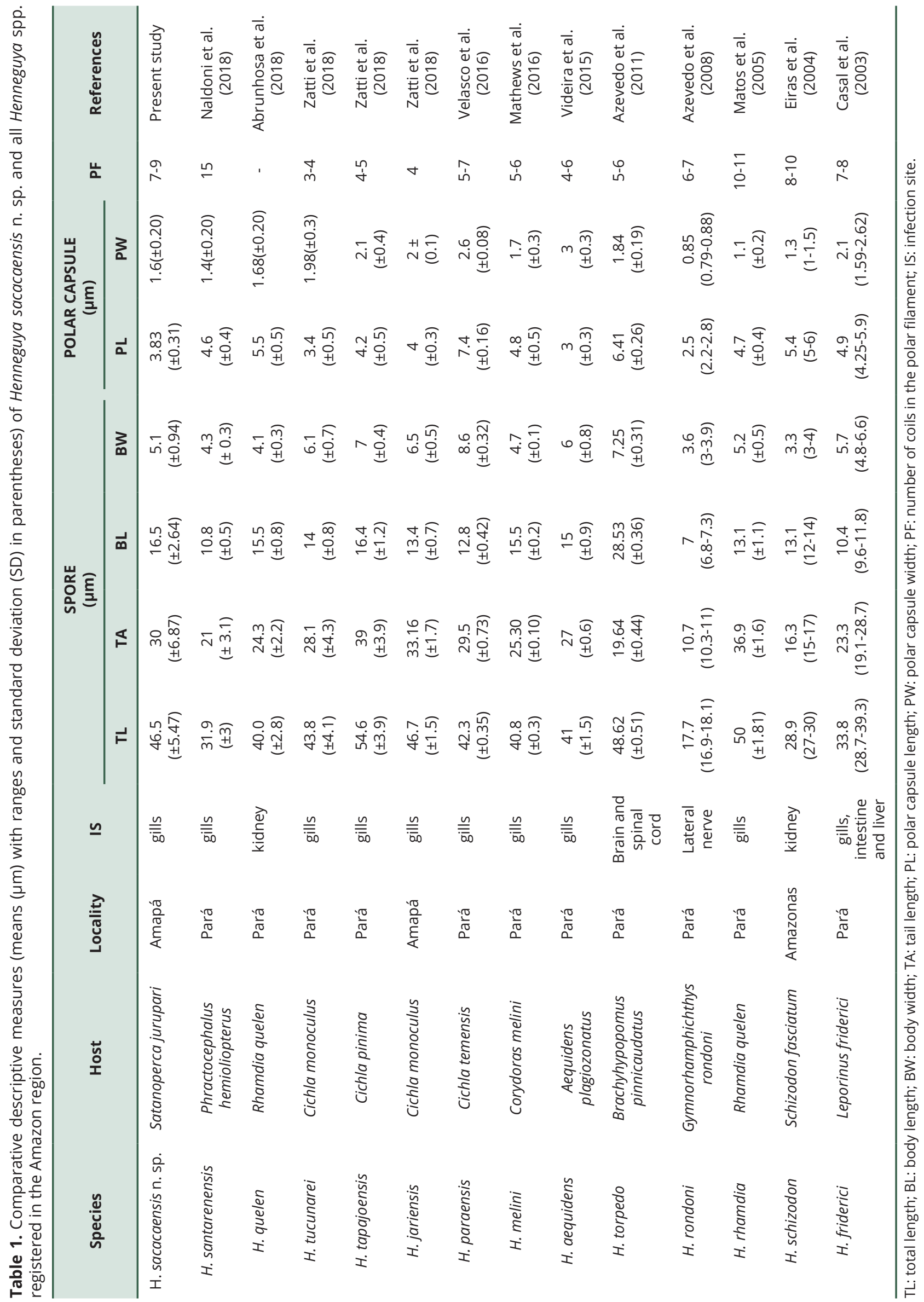




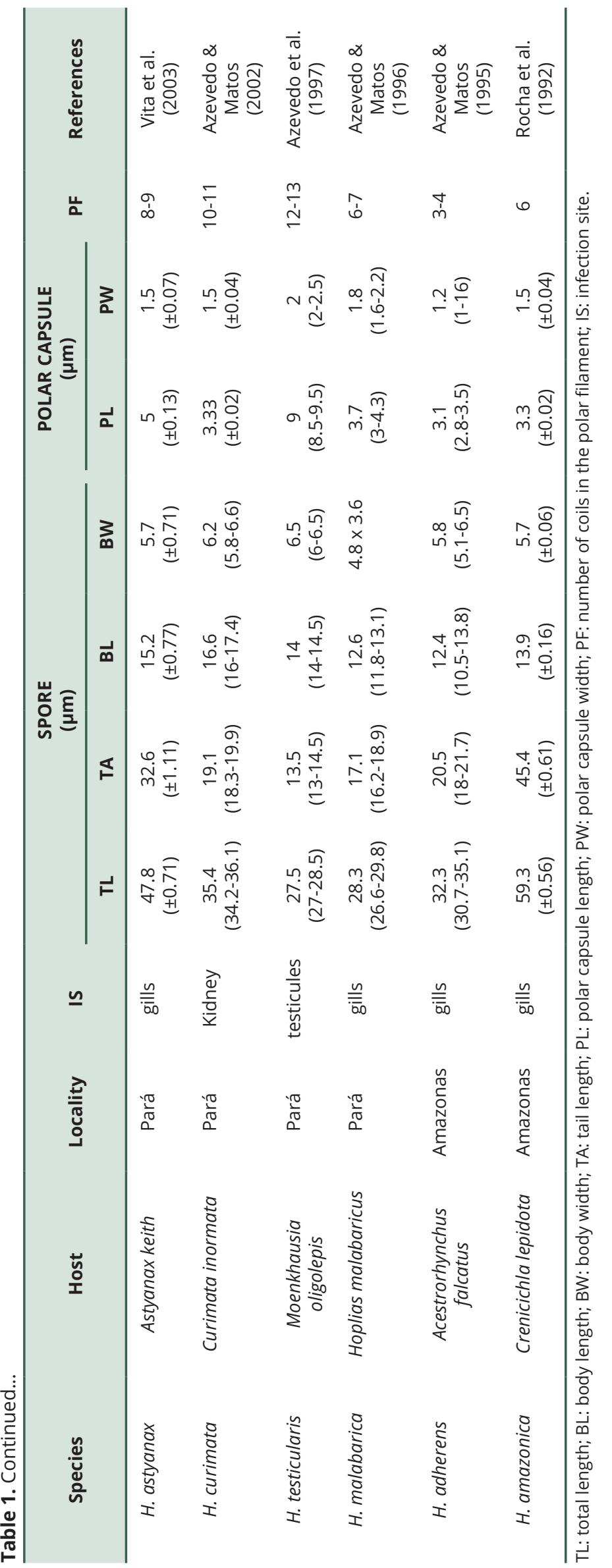




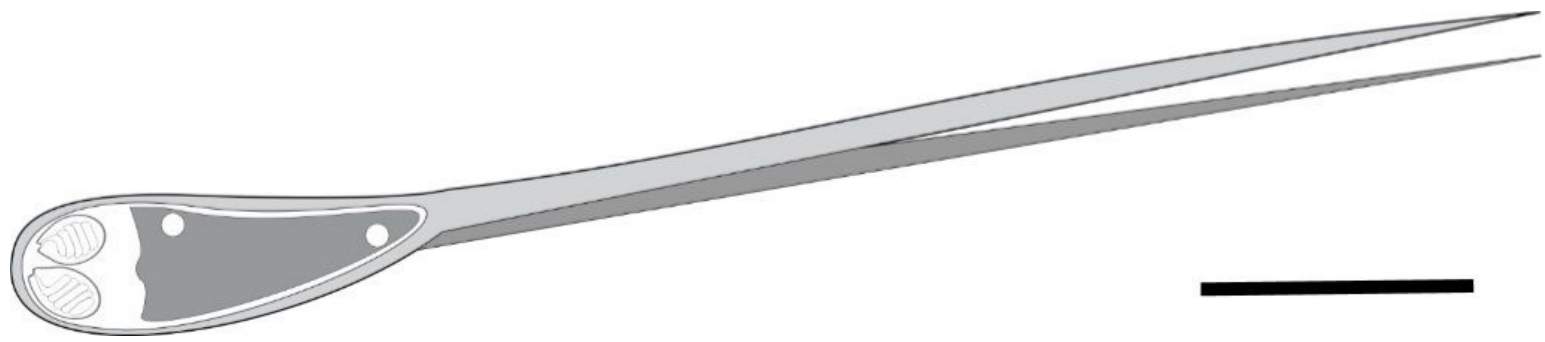

Figure 3. Drawing of Henneguya sacacaensis n. sp. Apical view of spore and polar capsules. Scale bar, $10 \mu \mathrm{m}$.

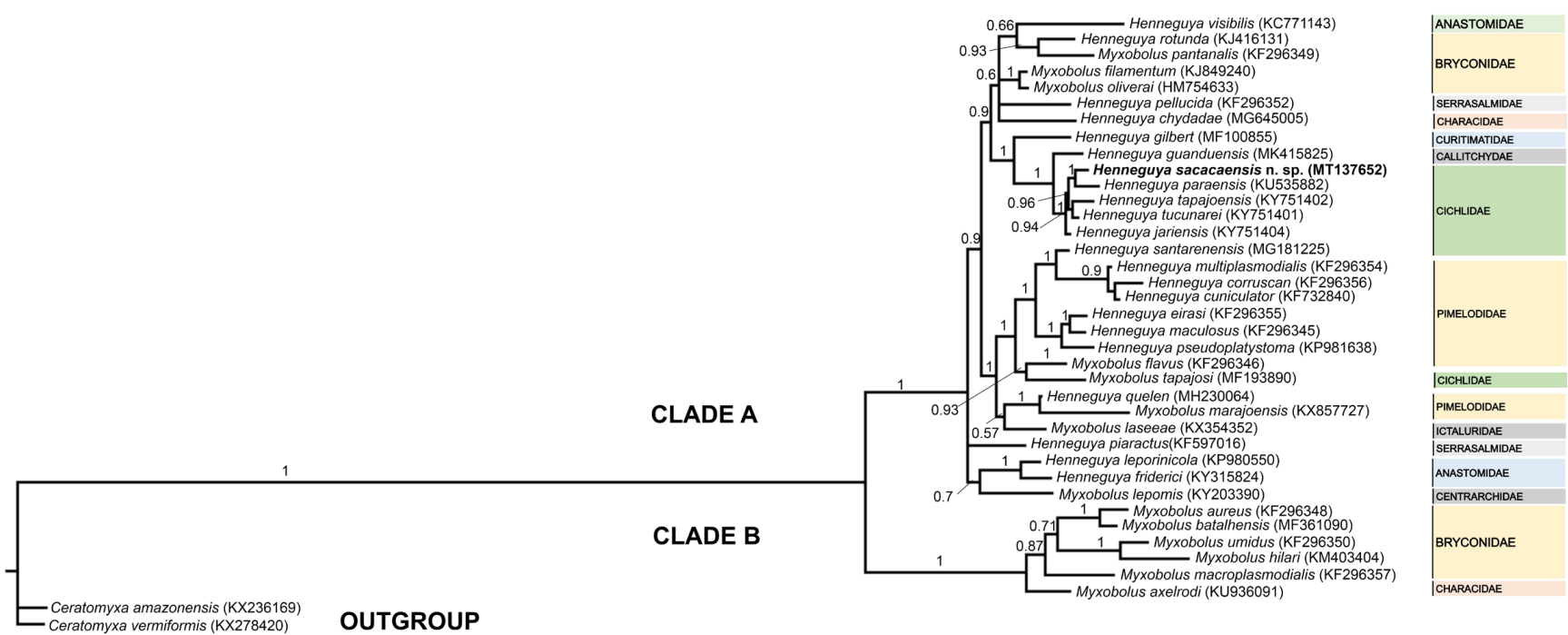

Figure 4. Phylogenetic tree generated by Bayesian inference (IB) through partial alignment of Henneguya sacacaensis n. sp. with SSU rDNA gene sequences of selected Henneguya and Myxobolus species. GenBank accession numbers are shown next to species names. Node numbers are indicated for posterior probability values calculated by IB. The new species is highlighted in bold and within the clade of Henneguya spp. in Cichlidae.

Table 2. The uncorrected $p$-distances recorded between pairs of Henneguya spp. that comprise the clade of registered cichlids in the Amazon.

\begin{tabular}{ccccc}
\hline Species & $\mathbf{1}$ & $\mathbf{2}$ & $\mathbf{3}$ \\
\hline (1) Henneguya sacacaensis n. sp. & & & & \\
(2) Henneguya jariensis & 0.08597 & & & \\
(3) Henneguya tapajoensis & 0.08525 & 0.04455 & 0.03950 \\
(4) Henneguya tucunarei & 0.06861 & 0.02911 & 0.07341 & 0.04783 \\
(5) Henneguya paraensis & 0.08009 & 0.05006 & & \\
\hline
\end{tabular}

\section{Discussion}

The characteristics of this myxosporidian are typical of the myxospore morphology of histozoic infection and development of cysts in host gills described by Lom \& Dyková (2006). The morphology of Henneguya sacacaensis n. sp. in this study was compared with other species of Henneguya described in the Amazon region.

In South America, about 100 species of the myxosporidian have been recorded in freshwater, being most of these species belonging to the Myxobolidae family, and the genera Myxobolus and Henneguya the most well-studied (Adriano \& Oliveira, 2018; Naldoni et al., 2018). In the Amazon region, the most species for this genus have been recorded in the state of Pará with 75\%, followed by Amazonas with 15\%, and Amapá with 10\%.

In the state of Amapá, only one species of myxosporidian has been described, Henneguya jariensis, parasitizing the fin of Cichla monoculus (Agassiz, 1831) (Zatti et al., 2018). Therefore, Henneguya sacacaensis n. sp. is the second myxosporidian species described in Amapá. 
The Henneguya spp. have been described to infect various sites in Amazonian fish including gills, kidneys, gallbladder, medulla, testicles, and brain. Velasco et al. (2016) described that the genus Henneguya has a strong tendency to form clades, taking into consideration aspects such as environment, order, and family of host fish. Other researchers describe this trend in their studies as well (Fiala, 2006; Ferguson et al., 2008; Adriano et al., 2012; Carriero et al., 2013; Moreira et al., 2014; Abrunhosa et al., 2018). The Henneguya sacacaensis n. sp. behaves similarly and group together with others that parasitize the Cichlidae family.

Among the Henneguya spp. that infect fish from the Amazon, the Henneguya amazonica stands out (Rocha et al., 1992), with the longest total length $(59.3 \mu \mathrm{m})$ and tail length $(45.4 \mu \mathrm{m})$. Being that Henneguya sacacaensis $\mathrm{n}$. $\mathrm{sp}$. has a total length of $46.5 \mu \mathrm{m}$ and tail length of $30 \mu \mathrm{m}$, only Henneguya astyanax (Vita et al., 2003) approaches it in relation to the total length $(47.8 \mu \mathrm{m})$ and Henneguya paraensis (Velasco et al., 2016$)$ is similar in tail length $(29.5 \mu \mathrm{m})$.

Regarding spores, the total length of Henneguya sacacaensis n. sp. $(16.5 \mu \mathrm{m})$ closely resembles Henneguya curimata $(16.6 \mu \mathrm{m})$ (Azevedo \& Matos, 2002), Henneguya tapajoensis (16.4 $\mu \mathrm{m})$ (Zatti et al., 2018), Henneguya quelen $(15.5 \mu \mathrm{m})$ (Abrunhosa et al., 2018), Henneguya melini (15.5 $\mu \mathrm{m})$ (Mathews et al., 2016), and Henneguya aequidens $(15.5 \mu \mathrm{m})$ (Videira et al., 2015). Henneguya sacacaensis n. sp. spore width $(5.1 \mu \mathrm{m})$ was similar to Henneguya rhamdia $(5.2 \mu \mathrm{m})$ (Matos et al., 2005).

Regarding polar capsule length, it is clear that Henneguya malabarica (Azevedo \& Matos, 1996) is similar to Henneguya sacacanesis n. sp., with lengths of $3.7 \mu \mathrm{m}$ and $3.8 \mu \mathrm{m}$, respectively, but the capsule width most closely resembled other species of the genus Henneguya. Henneguya sacacaensis n. sp. capsule width measure about $1.6 \mu \mathrm{m}$, which is more closely related to that of $H$. melini $(1.70 \mu \mathrm{m})$ and $H$. quelen $(1.68 \mu \mathrm{m})$.

Regarding the number of coils in the polar filament, Henneguya sacacaensis $\mathrm{n}$. $\mathrm{sp}$. has seven to nine coils. The number of coils in the polar filament varies from species to species: H. paraensis (5-7 coils), H. rhamdia (6-7 coils), Henneguya schtzodon (8-10 coils) (Eiras et al., 2004), Henneguya friderici (7-8 coils) (Casal et al., 2003), H. astyanax (8-9 coils), and H. malabarica (6-7 coils). Henneguya santarenensis (Naldoni et al., 2018) is recorded to have the highest known number of coils (15 coils).

Although the morphometric aspects are very similar to H. astyanax, the morphology of Henneguya sacacaensis n. sp. differs in the position of the binucleated cell. The binucleated cell of $H$. astyanax is just below the polar capsules, while in Henneguya sacacaensis n. sp., it is located at opposite ends in the sporoplasma. The sporoplasma also differs in its shape. Furthermore, the tail reinforces the difference in its arrangement, although there are no $H$. astyanax SSU rDNA data.

The gills of parasitized fish showed slight gill hyperplasia without lamellar fusion (Figure 2A and 5A); according to the classification by Molnár (2002), large cysts deform and press secondary lamellae laterally on both sides (Figure 5B).
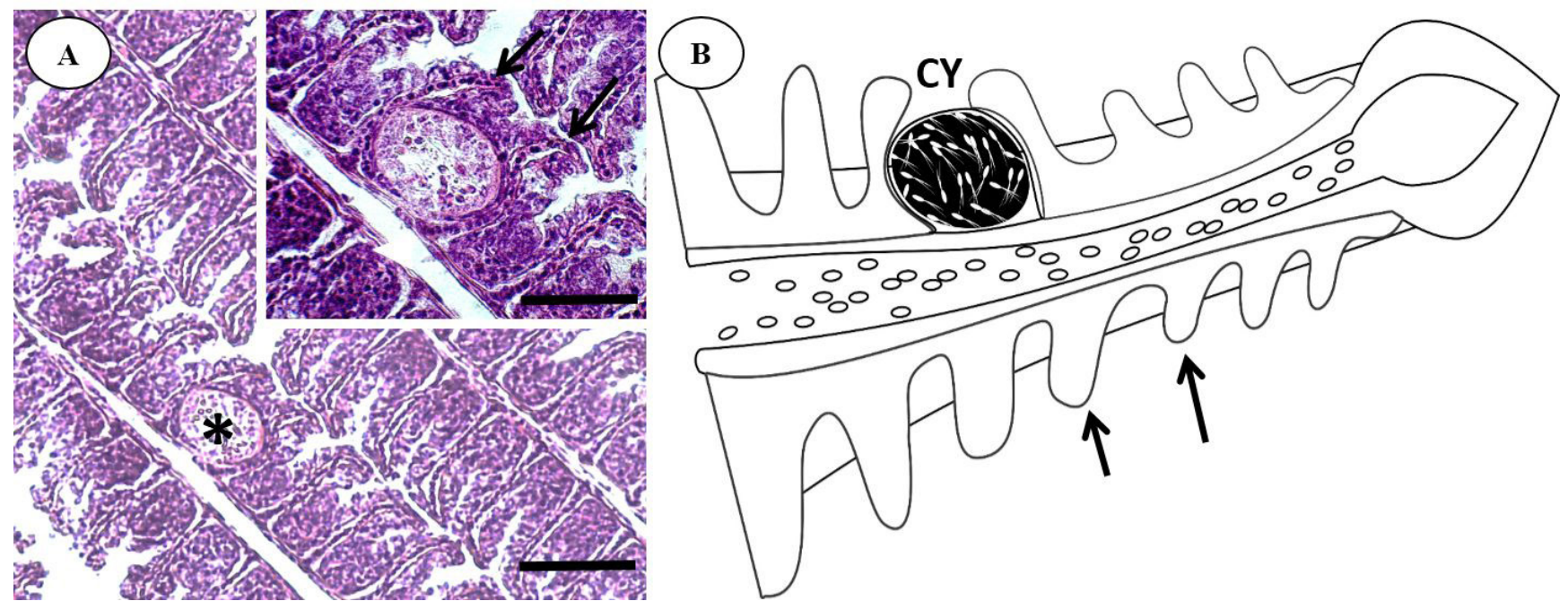

Figure 5. Gill tissue section of Satanoperca jurupari parasitized by Henneguya sacacaensis n. sp. (A) Cyst (*) between secondary lamellae with slight filamentous (intralamellar) hyperplasia. Insert: Cyst between secondary lamellae (arrows). Section stained with H\&E. Scale bar, $10 \mu \mathrm{m}$; (B) Drawing of the Henneguya cyst (CY) between the secondary lamellae (arrows). 
Similar changes have been described previously in other Amazon hosts such as Astyanax keithi (Vita et al., 2003), Cichla temensis (Velasco et al., 2016), Phractocephalus hemioliopterus (Naldoni et al., 2018), and Metynnis hypsauchen (Figueredo et al., 2020).

\section{Conclusion}

Thorough analysis of the morphological, morphometric, and molecular aspects allow us to describe a new species, Henneguya sacacaensis n. sp., with characteristics that differ from all other species previously described.

\section{Acknowledgements}

To the research group Health of Amazonian Aquatic Organisms (SOAA) of the Amapá State University (UEAP), the Carlos Azevedo Research Laboratory (LPCA) of the Federal Rural University of Amazonia (UFRA), the Laboratory of Applied Genetics (LGA)/UFRA, The Federal University of Amapá and the Higher Education Personnel Improvement Coordination (CAPES).

\section{References}

Abrunhosa J, Sindeaux-Neto JL, Hamoy I, Matos E. A new species of Myxosporea, Henneguya quelen, from silver catfish Rhamdia quelen (Siluriforme: Pimelodidae) in the Amazonian region. Parasitol Res 2018; 117(12): 3809-3820. http://dx.doi.org/10.1007/ s00436-018-6086-1. PMid:30255237.

Adriano EA, Arana S, Cordeiro NS. An ultrastructural and histopathological study of Henneguya pellucida n. sp. (Myxosporea: Myxobolidae) infecting Piaractus mesopotamicus (Characidae) cultivated in Brazil. Parasite 2005; 12(3): 221-227. http://dx.doi. org/10.1051/parasite/2005123221. PMid:16218209.

Adriano EA, Carriero MM, Maia AAM, Silva MRM, Naldoni J, Ceccarelli PS, et al. Phylogenetic and host-parasite relationship analysis of Henneguya multiplasmodialis n. sp. infecting Pseudoplatystoma spp. in Brazilian Pantanal wetland. Vet Parasitol 2012; 185(2-4): 110-120. http://dx.doi.org/10.1016/j.vetpar.2011.10.008. PMid:22051071.

Adriano EA, Oliveira OMP. Myxosporea. In: Jardim Botânico do Rio de Janeiro - JBRJ. Catálogo taxonômico da fauna do Brasil. Rio de Janeiro: PNUD; 2018.

Azevedo C, Casal G, Matos P, Alves A, Matos E. Henneguya torpedo sp. nov. (Myxozoa), a parasite from the nervous system of the Amazonian teleost Brachyhypopomus pinnicaudatus (Hypopomidae). Dis Aquat Organ 2011; 93(3): 235-242. http://dx.doi. org/10.3354/dao02292. PMid:21516976.

Azevedo C, Casal G, Matos P, Matos E. A new species of Myxozoa, Henneguya rondoni n. sp. (Myxozoa), from the peripheral nervous system of the Amazonian fish, Gymnorhamphichthys rondoni (Teleostei).J Eukaryot Microbio/ 2008; 55(3): 229-234. http:// dx.doi.org/10.1111/j.1550-7408.2008.00317.x. PMid:18460160.

Azevedo C, Corral L, Matos E. Light and ultrastructural data on Henneguya testicularis n. sp. (Myxozoa, Myxobolidae), a parasite from the testis of the Amazonian fish Moenkhausia oligolepis. Syst Parasitol 1997; 37(2): 111-114. http://dx.doi. org/10.1023/A:1005793930837.

Azevedo C, Matos E. Henneguya adherens n. sp. (Myxozoa, Myxosporea), parasite of the Amazonian fish, Acestrorhynchus falcatus. J Eukaryot Microbiol 1995; 42(5): 515-518. http://dx.doi.org/10.1111/j.1550-7408.1995.tb05898.x. PMid:7581326.

Azevedo C, Matos E. Henneguya malabarica sp. nov. (Myxozoa, Myxobolidae) in the Amazonian fish Hoplias malabaricus. Parasitol Res 1996; 82(3): 222-224. http://dx.doi.org/10.1007/s004360050099. PMid:8801553.

Azevedo C, Matos E. Fine structure of the Myxosporean, Henneguya curimata n. sp., parasite of the Amazonian fish, Curimata inormata (Teleostei, Curimatidae).J Eukaryot Microbio/ 2002; 49(3): 197-200. http://dx.doi.org/10.1111/j.1550-7408.2002.tb00522.x. PMid:12120984.

Barassa B, Adriano EA, Cordeiro NS, Arana S, Ceccarelli PS. Morphology and host-parasite interaction of Henneguya azevedoi n. sp., parasite of gills of Leporinus obtusidens from Mogi-Guaçu River, Brazil. Parasitol Res 2012; 110(2): 887-894. http://dx.doi. org/10.1007/s00436-011-2571-5. PMid:21842391.

Bush AO, Lafferty KD, Lotz JM, Shostak AW. Parasitology meets ecology on its own terms: Margolis et al. revisited. J Parasitol 1997; 83(4): 575-583. http://dx.doi.org/10.2307/3284227. PMid:9267395.

Carriero MM, Adriano EA, Silva MR, Ceccarelli PS, Maia AA. Molecular phylogeny of the Myxobolus and Henneguya genera with several new South American species. PLoS One 2013; 8(9): e73713. http://dx.doi.org/10.1371/journal.pone.0073713. PMid:24040037. 
Casal G, Matos E, Azevedo C. Light and electron microscopic study of the myxosporean, Henneguya friderici n. sp. from the Amazonian teleostean fish, Leporinus friderici. Parasitology 2003; 126(4): 313-319. http://dx.doi.org/10.1017/S0031182003002944. PMid:12741510.

Darriba D, Taboada GL, Doallo R, Posada D. jModelTest 2: more models, new heuristics and parallel computing. Nat Methods 2012; 9(8): 772. http://dx.doi.org/10.1038/nmeth.2109. PMid:22847109.

Dyková I, Lom J. Histopathological changes in fish gills infected with myxosporidian parasites of the genus Henneguya. J Fish Biol 1978; 12(3): 197-202. http://dx.doi.org/10.1111/j.1095-8649.1978.tb04165.x.

Eiras JC, Adriano EA. A checklist of new species of Henneguya Thélohan, 1892 (Myxozoa: Myxosporea, Myxobolidae) described between 2002 and 2012. Syst Parasitol 2012; 83(2): 95-104. http://dx.doi.org/10.1007/s11230-012-9374-7. PMid:22983797.

Eiras JC, Malta JC, Varela A, Pavanelli GC. Henneguya schizodon n. sp. (Myxozoa, Myxobolidae), a parasite of the Amazonian teleost fish Schizodon fasciatus (Characiformes, Anostomidae). Parasite 2004; 11(2): 169-173. http://dx.doi.org/10.1051/ parasite/2004112169. PMid:15224578.

Feist SW, Longshaw WM. Phylum Myxozoa. In: Woo PTK, editor. Fish diseases and disorders: protozoan and metazoan infections. 2nd ed. Oxfordshire: CAB International; 2006. p. 230-296. http://dx.doi.org/10.1079/9780851990156.0230.

Felsenstein J. Inferring phylogenies. Sunderland: Sinauer Associates; 2004.

Ferguson JA, Atkinson SD, Whipps CM, Kent ML. Molecular and morphological analysis of Myxobolus spp. of salmonid fishes with the description of a new Myxobolus species. J Parasito/ 2008; 94(6): 1322-1334. http://dx.doi.org/10.1645/GE-1606.1. PMid:19127969.

Fiala I. The phylogeny of Myxosporea (Myxozoa) based on small subunit ribosomal RNA gene analysis. Int J Parasito/ 2006; 36(14): 1521-1534. http://dx.doi.org/10.1016/j.ijpara.2006.06.016. PMid:16904677.

Figueredo RTA, Oliveira JEF, Vilhena MPSP, Berredo J, Santos WJP, Santos E, et al. Henneguyosis in gills of Metynnis hypsauchen: an Amazon freshwater fish. J Parasit Dis 2020; 44(1): 213-220. http://dx.doi.org/10.1007/s12639-019-01183-7. PMid:32174727.

Hall TA. BioEdit: a user-friendly biological sequence alignment editor and analysis program for Windows 95/98/NT. Nucleic Acids Symp Ser 1999; 41: 95-98.

Holzer AS, Bartošová-Sojková P, Born-Torrijos A, Lövy A, Hartigan A, Fiala I. The joint evolution of the Myxozoa and their alternate hosts: a cnidarian recipe for success and vast biodiversity. Mol Ecol 2018; 27(7): 1651-1666. http://dx.doi.org/10.1111/mec.14558. PMid:29575260.

Kaur H, Attri R. Morphological and molecular characterization of Henneguya bicaudi n. sp. (Myxosporea: Myxobolidae) infecting gills of Cirrhinus mrigala (Ham.) in Harike Wetland, Punjab (India). Parasitol Res 2015; 114(11): 4161-4167. http://dx.doi.org/10.1007/ s00436-015-4647-0. PMid:26239799.

László B, Csaba S, Kalman M. Atuais conhecimentos sobre Myxosporea (Myxozoa), parasitas de peixes: um estágio alternativo dos parasitas no Brasil. Braz J Vet Res Anim Sci 2002; 39(5): 271-276. http://dx.doi.org/10.1590/S1413-95962002000500010.

Lom J, Dyková I. Protozoan parasites of fishes. Amsterdam: Elsevier; 1992.

Lom J, Dyková I. Myxozoan genera: definition and notes on taxonomy, life-cycle terminology and pathogenic species. Folia Parasitol 2006; 53(1): 1-36. http://dx.doi.org/10.14411/fp.2006.001. PMid:16696428.

Mathews PD, Maia AAM, Adriano EA. Henneguya melini n. sp. (Myxosporea: Myxobolidae), a parasite of Corydoras melini (Teleostei: Siluriformes) in the Amazon region: morphological and ultrastructural aspects. Parasitol Res 2016; 115(9): 3599-3604. http:// dx.doi.org/10.1007/s00436-016-5125-z. PMid:27206653.

Matos E, Casal G, Matos P, Corral L, Azevedo C. Microrganismos parasitos de animais aquáticos da Amazônia. In: Ranzani-Paiva MJ, Takemoto RM, Lizama MAP, editors. Sanidade de organismos aquáticos. São Paulo: Varela; 2004. p. 158-178.

Matos E, Tajdari J, Azevedo C. Ultrastructural studies of Henneguya rhamdia n. sp. (Myxozoa) a parasite from the Amazon teleost fish, Rhamdia quelen (Pimelodidae).J Eukaryot Microbiol 2005; 52(6): 532-537. http://dx.doi.org/10.1111/j.1550-7408.2005.00063.x. PMid:16313446.

Molnár K. Taxonomic problems, seasonality and histopathology of Henneguya creplini (Myxosporea) infection of the pikeperch Stizostedion lucioperca in Lake Balaton. Folia Parasitol 1998; 45(4): 261-269. PMid:9868790.

Molnár K. Site preference of fish myxosporeans in the gill. Dis Aquat Organ 2002; 48(3): 197-207. http://dx.doi.org/10.3354/ dao048197. PMid:12033706.

Moreira GSA, Adriano EA, Silva MRM, Ceccarelli PS, Maia AAM. Morphology and 18S rDNA sequencing identifies Henneguya visibilis n. sp., a parasite of Leporinus obtusidens from Mogi Guaçu River, Brazil. Parasitol Res 2014; 113(1): 81-90. http://dx.doi. org/10.1007/s00436-013-3629-3. PMid:24100607. 
Morsy K, Abdel-Ghaffar F, Bashtar AR, Mehlhorn H, Al Quraishy S, Abdel-Gaber R. Morphology and small subunit ribosomal DNA sequence of Henneguya suprabranchiae (Myxozoa), a parasite of the catfish Clarias gariepinus (Clariidae) from the River Nile, Egypt. Parasitol Res 2012; 111(4): 1423-1435. http://dx.doi.org/10.1007/s00436-012-2976-9. PMid:22699967.

Naldoni J, Arana S, Maia AAM, Ceccarelli PS, Tavares LER, Borges FA, et al. Henneguya pseudoplatystoma n. sp. causing reduction in epithelial area of gills in the farmed pintado, a South American catfish: histopathology and ultrastructure. Vet Parasito/ 2009; 166(1-2): 52-59. http://dx.doi.org/10.1016/j.vetpar.2009.07.034. PMid:19695782.

Naldoni J, Maia AAM, Correa LL, Silva MRM, Adriano EA. New myxosporeans parasitizing Phractocephalus hemioliopterus from Brazil: morphology, ultrastructure and SSU-rDNA sequencing. Dis Aquat Organ 2018; 128(1): 37-49. http://dx.doi.org/10.3354/ dao03210. PMid:29565252.

Pote LM, Hanson LA, Shivaji R. Small subunit ribosomal RNA sequences link the cause of proliferative gill disease in channel catfish to Henneguya n. sp. (Myxozoa: myxosporea). Aquat Anim Health 2000; 12(3): 230-240. http://dx.doi.org/10.1577/15488667(2000)012<0230:SSRRSL>2.0.CO;2.

Reis RE, Albert JS, Di Dario F, Mincarone MM, Petry P, Rocha LA. Fish biodiversity and conservation in South America. J Fish Biol 2016; 89(1): 12-47. http://dx.doi.org/10.1111/jfb.13016. PMid:27312713.

Rocha E, Matos E, Azevedo C. Henneguya amazonica n. sp. (Myxozoa, Myxobolidae), parasitizing the gills of Crenicichla lepidota Heckel, 1840 (Teleostei, Cichlidae) from Amazon River. Eur J Protistol 1992; 28(3): 273-278. http://dx.doi.org/10.1016/S09324739(11)80233-6. PMid:23195230.

Ronquist F, HuelsenbeckJP. MrBayes 3: bayesian phylogenetic inference under mixed models. Bioinformatics 2003; 19(12): 15721574. http://dx.doi.org/10.1093/bioinformatics/btg180. PMid:12912839.

Swofford DL. PAUP*: Phylogenetic analysis using parsimony ( ${ }^{*}$ and other methods). Sunderland: Sinauer Associates; 2003.

Velasco M, Videira M, Nascimento LC, Matos P, Gonçalves EC, Matos E. Henneguya paraensis n. sp.(Myxozoa; Myxosporea), a new gill parasite of the Amazonian fish Cichla temensis (Teleostei: Cichlidae): morphological and molecular aspects. Parasitol Res 2016; 115(5): 1779-1787. http://dx.doi.org/10.1007/s00436-016-4916-6. PMid:26847632.

Videira M, Velasco M, Azevedo R, Silva R, Gonçalves E, Matos P, et al. Morphological aspects of Henneguya aequidens n. sp. (Myxozoa: Myxobolidae) in Aequidens plagiozonatus Kullander, 1984 (Teleostei: Cichlidae) in the Amazon region, Brazil. Parasitol Res 2015; 114(3): 1159-1162. http://dx.doi.org/10.1007/s00436-014-4295-9. PMid:25573695.

Vita P, Corral L, Matos E, Azevedo C. Ultrastructural aspects of the myxosporean Henneguya astyanax n. sp. (Myxozoa: Myxobolidae), a parasite of the Amazonian teleost Astyanax keithi (Characidae). Dis Aquat Organ 2003; 53(1): 55-60. http://dx.doi.org/10.3354/ dao053055. PMid:12608569.

Zatti SA, Atkinson SD, Maia AAM, Bartholomew JL, Adriano EA. Novel Henneguya spp. (Cnidaria: Myxozoa) from cichlid fish in the Amazon basin cluster by geographic origin. Parasitol Res 2018; 117(3): 849-859. http://dx.doi.org/10.1007/s00436-018-5762-5. PMid:29374784. 